\title{
Malaysian Yournal of Microbiology \\ Morphological and molecular characterization of Trichoderma species isolated from rhizosphere soils in Malaysia
}

\author{
Sharifah Siti Maryam Syd Abdul Rahman, Nur Ain Izzati Mohd Zainudin*, Asma Aris and Nor Azwady Abd Aziz \\ Department of Biology, Faculty of Science, Universiti Putra Malaysia, 43400 Serdang, Selangor, Malaysia \\ Email: ainizzati@upm.edu.my
}

Received 11 June 2020; Received in revised form 4 September 2020; Accepted 21 October 2020

\begin{abstract}
Aims: Knowledge of the Trichoderma taxa is important for both control efficiency and environmental conservation. Therefore, the objective of this study is to isolate and identify Trichoderma species from various rhizosphere soil samples using phenotypic and molecular characterization.

Methodology and results: Native Trichoderma spp. were isolated from agricultural fields in 17 sites from seven states of Malaysia. These isolates were characterized via morphological observation and molecular phylogenetic analysis based on the translation elongation factor-1 $\alpha$ (tef1- $\alpha$ ) gene. About 42 isolates were classified into eight Trichoderma species, which are Trichoderma asperellum, T. hamatum, T. harzianum, T. koningiopsis, T. rodmanii, T. spirale, T. viride and T. virens. Comparison of DNA sequences of tef1-a showed that the isolates were $98-100 \%$ similar to respective Trichoderma species from GenBank, thus confirming the fungal identity. Phylogenetic trees of maximum likelihood (ML) dataset of tef1- $\alpha$ inferred that the isolates were clustered according to species.

Conclusion, significance and impact of study: Findings in the present study will be beneficial for the purposes of biodiversity conservation and plant disease management using biocontrol agents.
\end{abstract}

Keywords: Filamentous fungi, morphology, translation elongation factor, Trichoderma, soil

\section{INTRODUCTION}

Trichoderma is a rhizocompetent filamentous fungi that free-living and can be found in all types of soil especially in agricultural soil (Samuels, 2006). They are genetically diverse and can be found on decaying wood, bark, and other plant-decomposed materials that may attribute to their diverse metabolic capability and aggressive competitive nature (Howell, 2003; Lorito et al., 2010). These characteristics make them significant decomposers of woody and herbaceous material and are necrotrophic against other decomposers. In addition, they are important for soil fertility (Contreras-Cornejo et al., 2009; Lorito et al., 2010). They are extremely helpful in maintaining soil function, can colonize the root and populate the rhizosphere (Ahmad et al., 2011). As soil fungi, Trichoderma can survive in various type of media such as top soil, mixed soil and some of the agro wastes where coconut fiber best promotes sporulation (Easa Hasan et al., 2020).

Trichoderma species are among the most studied fungal biological control agents and commercially marketed as biopesticides (Harman, 2000). Trichoderma can act as a secondary opportunistic invader, a fastgrowing fungus, a strong spore producer, a source of cell wall degrading enzymes and important antibiotic producers (Vinale et al., 2008). Trichoderma also plays key roles in suppressing soil-borne plant diseases and promoting plant growth (Garbeva et al., 2004; Lorito et al., 2010). These diverse activities of Trichoderma render them a beneficial component of the soil ecosystem. Based on Suhaida and Nur Ain Izzati (2013), the application of $T$. harzianum T73s has successfully inhibited the Fusarium ear rot of maize.

Trichoderma spp. have recently received greater attention in nanotechnology such as in the synthesis of several bioactive inorganic nanoparticles (Guilger et al., 2017; Elamawi et al., 2018). On top of that, biodiversity conservation of fungi is underestimated although they are important agents influencing the biodiversity of an ecosystem. Therefore, this study was conducted to isolate Trichoderma species from various soil samples and to identify the isolates at species level using phenotypic and molecular characterization. The present study may provide useful isolates, which in the future can be used for disease management strategies in preventing diseases, enhance plant growth, and increasing the yields. 


\section{MATERIALS AND METHODS}

\section{Soil sampling}

Rhizosphere soils of different cultivated crops were obtained from 17 sampling locations in seven states (Kedah, Melaka, Pahang, Perak, Sabah, Selangor and Terengganu) throughout Malaysia (Table 1). The sampling locations were selected based on availability and accessibility to collect the soil samples. The soil samples $(200 \mathrm{~g})$ were collected in triplicate by using a sterile trowel at depth $10 \mathrm{~cm}$ within a radius of $0.5 \mathrm{~m}$ around the trunk or stem of plants. The soil samples were kept in an envelope paper and stored at $4{ }^{\circ} \mathrm{C}$ until being used.

\section{Fungal isolation and purification}

Fungal species were isolated from soil samples using dilution plating by mixing $10 \mathrm{~g}$ of soil with $100 \mathrm{~mL}$ sterile distilled water before agitating on a shaker (Infors HT) at $100 \mathrm{rpm}$ for $10 \mathrm{~min}$. The soil was diluted until $10^{-3}$ and every $1 \mathrm{~mL}$ of the final dilution from $10^{-1}$ until $10^{-3}$ diluted soil solution was pipetted into a Petri dish and was done in triplicate. About $9 \mathrm{~mL}$ of Rose Bengal agar (RBA) was poured into the Petri dish of diluted soil, swirled gently, and left to solidify. The soil plates were examined daily and fungal colonies that had been grown on RBA were subculture onto Potato Dextrose Agar (PDA). Single spore isolation was carried out on a new PDA to obtain the pure culture of Trichoderma isolates.

\section{Morphological characteristics of Trichoderma species}

The Trichoderma isolates were tentatively identified into the species level based on macro- and micromorphological characteristics and species confirmation by molecular analysis. For macromorphological observation, the isolates were grown on PDA. The colony feature, conidia shape and size, pigmentation and sporulation pattern were observed, and the growth rate was measured.

The side culture technique was used to observe the micromorphological features of Trichoderma. A block (1 $\mathrm{cm}^{2}$ ) of PDA was placed on a sterile slide and then cultured with Trichoderma on all four sides of the agar block and covered with a coverslip. The culture was then incubated for 3 days $\left(28 \pm 2^{\circ} \mathrm{C}\right)$ in a sterile glass Petri dish layer with damp filter paper. A sterile coverslip was put on the slide and then observed under a microscope. The slide culture was examined using a 40× magnification under a light microscope (Olympus CX 21, America Inc.). Trichoderma species were identified via microscopic observation of the morphology of conidia, conidiophore, phialides, and chlamydospore using taxonomic keys (Samuels et al., 2012).
Table 1: Locations of soil sampling with their respective crop.

\begin{tabular}{|c|c|c|}
\hline State & City & Crop \\
\hline Kedah & Langkawi & Paddy \\
\hline Melaka & Telok Mas & Mango \\
\hline \multirow{2}{*}{ Pahang } & Maran & Rubber, oil palm \\
\hline & Cameron Highland & Cabbage \\
\hline Perak & $\begin{array}{l}\text { Segari } \\
\text { Bidor }\end{array}$ & Oil palm \\
\hline Sabah & Kundasang & Banana \\
\hline \multirow{8}{*}{ Selangor } & Meru & Banana, rubber \\
\hline & Tanjung Karang & Paddy \\
\hline & Serdang & Banana, papaya \\
\hline & Banting & \multirow{4}{*}{ Oil palm } \\
\hline & Hulu Selangor & \\
\hline & Kajang & \\
\hline & Semenyih & \\
\hline & Dengkil & $\begin{array}{l}\text { Oil palm, banana, } \\
\text { jackfruit }\end{array}$ \\
\hline Terengganu & $\begin{array}{l}\text { Bukit Besi } \\
\text { Ketengah }\end{array}$ & Oil palm \\
\hline
\end{tabular}

\section{Translation Elongation Factor 1 Alpha (TEF-1 $\alpha$ ) sequence analysis}

Isolates were grown on PDA and incubated at $28 \pm 2{ }^{\circ} \mathrm{C}$ for 3 days. DNA was extracted using UltraClean $\AA$ Microbial DNA Isolation Kit (MO BIO, Carlsbad, CA, USA), following the manufacturers protocol. The gDNA was stored in $-20^{\circ} \mathrm{C}$. Translation Elongation Factor (tef) 1a region of genomic DNA of all Trichoderma isolates were amplified using a TProfessional Standard Thermocycler (Biometra Company). For tef-1a amplification, the PCR mixture was completed by using $25 \mu \mathrm{L}$ reaction master mix that contains $5 \mu \mathrm{L}$ of $5 \times$ PCR buffer, $1.25 \mu \mathrm{L}$ of $0.5 \mu \mathrm{M}$ primer, $2.5 \mu \mathrm{L}$ of $0.2 \mathrm{mM}$ deoxynucleotide triphosphate (dNTPs), $2.5 \mu \mathrm{L}$ of $2.5 \mathrm{mM}$ Magnesium chloride $\left(\mathrm{MgCl}_{2}\right), 0.125$ unit of Taq Polymerase and $20 \mathrm{ng}$ of the DNA template. A set of primer was used: EF1728F (5'CATCGAGAAGTTCGAGAAGG-3') and TEF1LLErev (5'AACTTGCAGGCAATGTGG-3') (Jaklitsch and Voglmayr, 2015). The PCR cycling for tef- $1 \alpha$ was conducted as follows: initial denaturation at $94{ }^{\circ} \mathrm{C}$ for $85 \mathrm{sec}$, followed by 35 cycles of denaturation at $95{ }^{\circ} \mathrm{C}$ for $35 \mathrm{sec}$, annealing at $58{ }^{\circ} \mathrm{C}$ for $55 \mathrm{sec}$, extension at $72{ }^{\circ} \mathrm{C}$ for 90 $\mathrm{sec}$, final extension at $72{ }^{\circ} \mathrm{C}$ for $10 \mathrm{~min}$ and kept at $4{ }^{\circ} \mathrm{C}$ until further use.

About $5 \mu \mathrm{L}$ PCR products were loaded in $1.5 \%$ agarose gel with $0.1 \%$ FloroSafe DNA stain and undergone electrophoresis for $35 \mathrm{~min}$ at $90 \mathrm{~V}$. The amplicon of tef- $1 \alpha$ regions in size between 1.0-1.2 kb was determined based on its migration and conformation relative to the $1.0 \mathrm{~kb}$ molecular size marker (BIORON $\mathrm{GmbH}$, Germany) and 6x Loading Dye (Thermo Fisher Scientific, Carlsbad, California). PCR products were purified using QIAGEN (QIAquick ${ }^{\circledR}$ Gel Extraction Kit) following the manufacturer's instruction. The purified PCR 
products of tef- $1 \alpha$ were sequenced using an Applied Biosystem 3730xl DNA Analyzer (MyTACG Bioscience Enterprise, Selangor, Malaysia).

Sequence similarity searches were performed for each of the representative fungal sequences by BLAST and compared to the sequences in GenBank by using the Standard Nucleotide BLAST network services for similarities present in the National Centre for Biotechnology Information (NCBI) database (http://www.ncbi.nlm.nih.gov/) (Huang et al., 2009). ClustalW of MEGA $X$ software was used to generate the consensus sequences to align the consensus sequence to each other and to the sequences in GenBank (Kumar et al., 2018). All the assembled sequences were deposited to GenBank, NCBI (http://www.ncbi.nlm.nih.gov/).

\section{RESULTS AND DISCUSSION}

A total of 42 isolates of Trichoderma were successfully obtained from rhizosphere soils of different crops that collected from 17 different sampling sites around Malaysia. The most frequently isolated species were $T$. asperellum (11 isolates) followed by $T$. virens (8 isolates), $T$. harzianum (7 isolates), T. koningiopsis (7 isolates), $T$. viride (4 isolates), T. hamatum (3 isolates), T. spirale (1 isolate) and $T$. rodmanii (1 isolate). The differences in macro- and micromorphological characteristics of eight Trichoderma species were summarized in Table 2. Trichoderma has gained immense significance since years ago which reflects to its biocontrol properties against various plant pathogens and their ability to promote plant growth. Until 2015, 256 names of Trichoderma species have been listed (Bissett et al., 2015).

Tef1 is one of the best-resolving markers used for species identification of Trichoderma, in categorized separation at the species level (Lorito et al., 2010; Jaklitsch and Voglmayr, 2015). The tef-1a region was successfully amplified and the amplicon size ranged between 1.0-1.2 kb (Figure 1). The sequences showed a value of $89-99 \%$ similarity with sequences in GenBank. The maximum-likelihood analysis resulted in the isolates of the same species that were grouped in the same cluster (Figure 2). Table 3 shows the accession numbers of Trichoderma isolates that have been deposited in Genbank (http://www.ncbi.nlm.nih.gov/).

The colonies of Trichoderma species proliferated on PDA with growth rate ranging from 2.00 to $2.80 \mathrm{~cm} /$ day and many isolates produced concentric rings which grow outwards from the center of the colonies. All of the fungi initially produced a pure white mycelium, which gradually turned to green, or yellow-green in colour except for $T$. koningiopsis, where all the isolates remain white, however, after being incubated more than 14 days the mycelia colour gradually turned to green. The pigmentation and the concentration of the phialospores gave rise to the green colour of the colony. The conidiophore branching structure and the conidial shape were variables between species (Table 2 ).

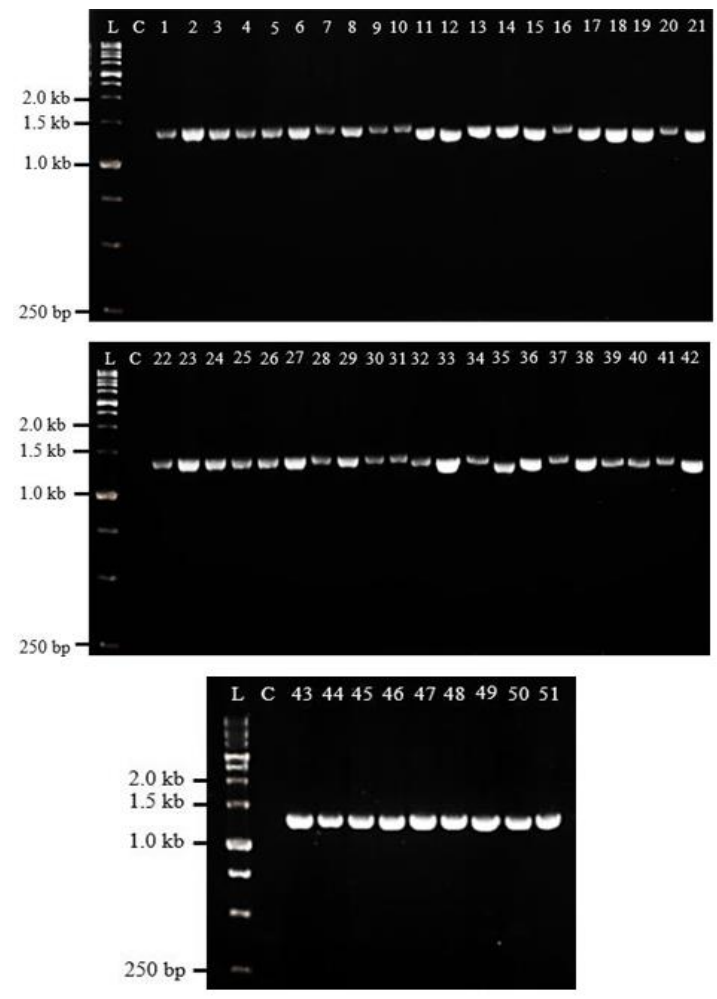

Figure 1: The banding pattern of TEF-1a gene amplification. Expected band size ranging from 1.0-1.2 kb. Lane 1-42: isolate A190s, A237s, B8s, B99s, B101s, B108s, B129s, B142s, B304s, B1581, B1584, B1881, B1890, B1895, B1896, B1902, B1952, B2115, B2230, B2235, C261s, C1665, C1667, C1932, K1968, K1970, M1891, T2005, T2007, T2014, T2018, T2023, T2031, T2034, T2037, T2040, T2045, T2052, T2073, S1972, S1984 and S1987. Lane L: Marker 1.0kb, Lane C: Control.

Macromorphology of Trichoderma asperellum in the PDA plate is sparse cottony from whitish mycelia to whitish green and then dull green in colour (Figure 3A-B). It also formed 1-2 concentric rings with green conidial production. The conidia production was denser in the center than towards the margins of the PDA plate. It has many green spores. $T$. asperellum was also a rapid growth colony on PDA that ranged between 20.0-25.0 $\mathrm{mm} /$ day and covered the full plate within four days. As shown in Figure 1, T. asperellum formed in repeatedly paired branches conidiophores along the main axis (Figure 3C-D). The phialospores of $T$. asperellum were subglobose to ovoid with smooth-walled (Figure 3E). $T$. asperellum also produced terminal or apical subglobose and granulated chlamydospores (Figure 3F). The phialides formed cylindrical shapes, which enlarged at the opposite side of the phialospores position (Figure 3G). The phialospores formed were cluster accumulated at the tips of phialides and formed a globose conidial head. Morphological of $T$. asperellum reported in this study agrees with a previous study by Wijesinghe et al. (2010). 
Malays. J. Microbiol. Vol 17(1) 2021, pp. 80-89

DOI: http://dx.doi.org/10.21161/mjm.200893

Table 2: Macro- and micromorphological characteristics of Trichoderma species.

\begin{tabular}{|c|c|c|c|c|c|c|}
\hline \multirow{2}{*}{$\begin{array}{l}\mathscr{\Phi} \\
\frac{1}{0} \\
\text { के }\end{array}$} & \multicolumn{2}{|c|}{ Phialospore } & \multirow{2}{*}{ Phialides } & \multirow{2}{*}{ Conidiophores } & \multirow{2}{*}{ Chlamydospores } & \multirow{2}{*}{$\begin{array}{l}\text { Colony } \\
\text { colour on } \\
\text { PDA }\end{array}$} \\
\hline & Size $(\mu \mathrm{m})$ & Shape & & & & \\
\hline 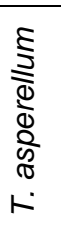 & $\begin{array}{c}3.25-3.50 \\
\times \\
2.80-3.00\end{array}$ & $\begin{array}{l}\text { Subglobose } \\
\text { to short ovoid } \\
\text { with smooth } \\
\text { walled }\end{array}$ & $\begin{array}{l}\text { Cylindrical shape; } \\
\text { enlarged on opposite } \\
\text { side of the } \\
\text { phialospores position }\end{array}$ & $\begin{array}{l}\text { Repeated paired } \\
\text { branches along } \\
\text { the main axis }\end{array}$ & $\begin{array}{l}\text { Apical } \\
\text { subglobose and } \\
\text { granulate }\end{array}$ & $\begin{array}{l}\text { Whitish to } \\
\text { dull green }\end{array}$ \\
\hline 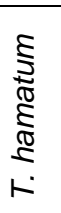 & $\begin{array}{c}3.40-5.00 \\
\times \\
2.70-3.95\end{array}$ & Ellipsoidal & $\begin{array}{l}\text { Short swollen bottle- } \\
\text { like pear shaped }\end{array}$ & $\begin{array}{l}\text { Long and thick } \\
\text { with short and } \\
\text { thick } \\
\text { branches }\end{array}$ & $\begin{array}{lr}\text { Terminal } & \text { and } \\
\text { intercalary } & \text { in } \\
\text { globose } & \text { with } \\
\text { granulate } & \end{array}$ & $\begin{array}{l}\text { Whitish to } \\
\text { yellowish } \\
\text { green }\end{array}$ \\
\hline $\begin{array}{l}\frac{5}{D} \\
\frac{\pi}{N} \\
\frac{\pi}{2} \\
r \\
r\end{array}$ & $\begin{array}{c}2.48-3.25 \\
\times \\
2.21-2.85\end{array}$ & $\begin{array}{l}\text { Subglobose } \\
\text { to short } \\
\text { obovoid }\end{array}$ & $\begin{array}{l}\text { Cylindrical shape } \\
\text { which swollen-like at } \\
\text { the middle }\end{array}$ & $\begin{array}{l}\text { Paired branches } \\
\text { along the main } \\
\text { mycelia axis }\end{array}$ & $\begin{array}{lr}\text { Terminal and } \\
\text { intercalary in } \\
\text { globose or oval }\end{array}$ & $\begin{array}{l}\text { Whitish to } \\
\text { dull almost } \\
\text { dark green }\end{array}$ \\
\hline 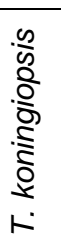 & $\begin{array}{c}3.00-4.00 \\
\times \\
2.00-3.00\end{array}$ & $\begin{array}{l}\text { Ellipsoidal } \\
\text { with smooth- } \\
\text { walled }\end{array}$ & Long cylindrical shape & $\begin{array}{l}\text { Formed in long } \\
\text { branches }\end{array}$ & $\begin{array}{lr}\text { Terminal } & \text { and } \\
\text { intercalary } & \text { in } \\
\text { globose } & \end{array}$ & $\begin{array}{l}\text { Cottony } \\
\text { tufted } \\
\text { whitish } \\
\text { and turned } \\
\text { green }\end{array}$ \\
\hline $\begin{array}{l}:= \\
\frac{1}{0} \\
\frac{1}{0} \\
:\end{array}$ & $\begin{array}{c}4.00-5.50 \\
\times \\
2.80-4.50\end{array}$ & $\begin{array}{l}\text { Elliptical- } \\
\text { subcylindrical }\end{array}$ & $\begin{array}{l}\text { Long cylindrical shape } \\
\text { swollen near the tips }\end{array}$ & $\begin{array}{l}\text { Paired branches } \\
\text { on the tips }\end{array}$ & $\begin{array}{l}\text { Terminal and } \\
\text { intercalary in } \\
\text { globose and oval } \\
\text { with granulated }\end{array}$ & $\begin{array}{l}\text { Whitish to } \\
\text { slight dark } \\
\text { green }\end{array}$ \\
\hline $\begin{array}{l}\frac{0}{\sqrt[T]{2}} \\
\frac{0}{\infty} \\
r\end{array}$ & $\begin{array}{c}3.40-4.50 \\
\times \\
2.30-2.55\end{array}$ & Ellipsoidal & Cylindrical long shape & $\begin{array}{l}\text { Repeated paired } \\
\text { branches along } \\
\text { the main axis }\end{array}$ & $\begin{array}{l}\text { Terminal and } \\
\text { intercalary in } \\
\text { globose in shape } \\
\text { with granulated }\end{array}$ & $\begin{array}{l}\text { Whitish to } \\
\text { slight dull } \\
\text { green }\end{array}$ \\
\hline $\begin{array}{l}\frac{\infty}{2} \\
\stackrel{2}{2} \\
r\end{array}$ & $\begin{array}{c}2.00-2.25 \\
\times \\
2.21-2.55\end{array}$ & $\begin{array}{l}\text { Globose in } \\
\text { shape }\end{array}$ & $\begin{array}{l}\text { Cylindrical shaped } \\
\text { with enlarged at the } \\
\text { uneven } \\
\text { branched body }\end{array}$ & $\begin{array}{l}\text { Uneven number } \\
\text { paired branched } \\
\text { of phialides }\end{array}$ & $\begin{array}{lr}\text { Terminal and } \\
\text { intercalary in } \\
\text { globose and oval } \\
\text { in shape with } \\
\text { granulated }\end{array}$ & $\begin{array}{l}\text { Whitish to } \\
\text { dull green }\end{array}$ \\
\hline 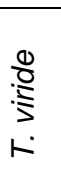 & $\begin{array}{c}3.30-3.50 \\
\times \\
2.50-3.05\end{array}$ & $\begin{array}{l}\text { Subglobose } \\
\text { or obovoid }\end{array}$ & $\begin{array}{l}\text { Cylindrical swollen and } \\
\text { some were bend at the } \\
\text { tips }\end{array}$ & $\begin{array}{lr}\text { Uneven } & \text { paired } \\
\text { phialides like } \\
\text { whorled shaped }\end{array}$ & $\begin{array}{l}\text { Terminal and } \\
\text { intercalary in } \\
\text { globose or oval in } \\
\text { shape }\end{array}$ & $\begin{array}{l}\text { Whitish to } \\
\text { green } \\
\text { yellow }\end{array}$ \\
\hline
\end{tabular}




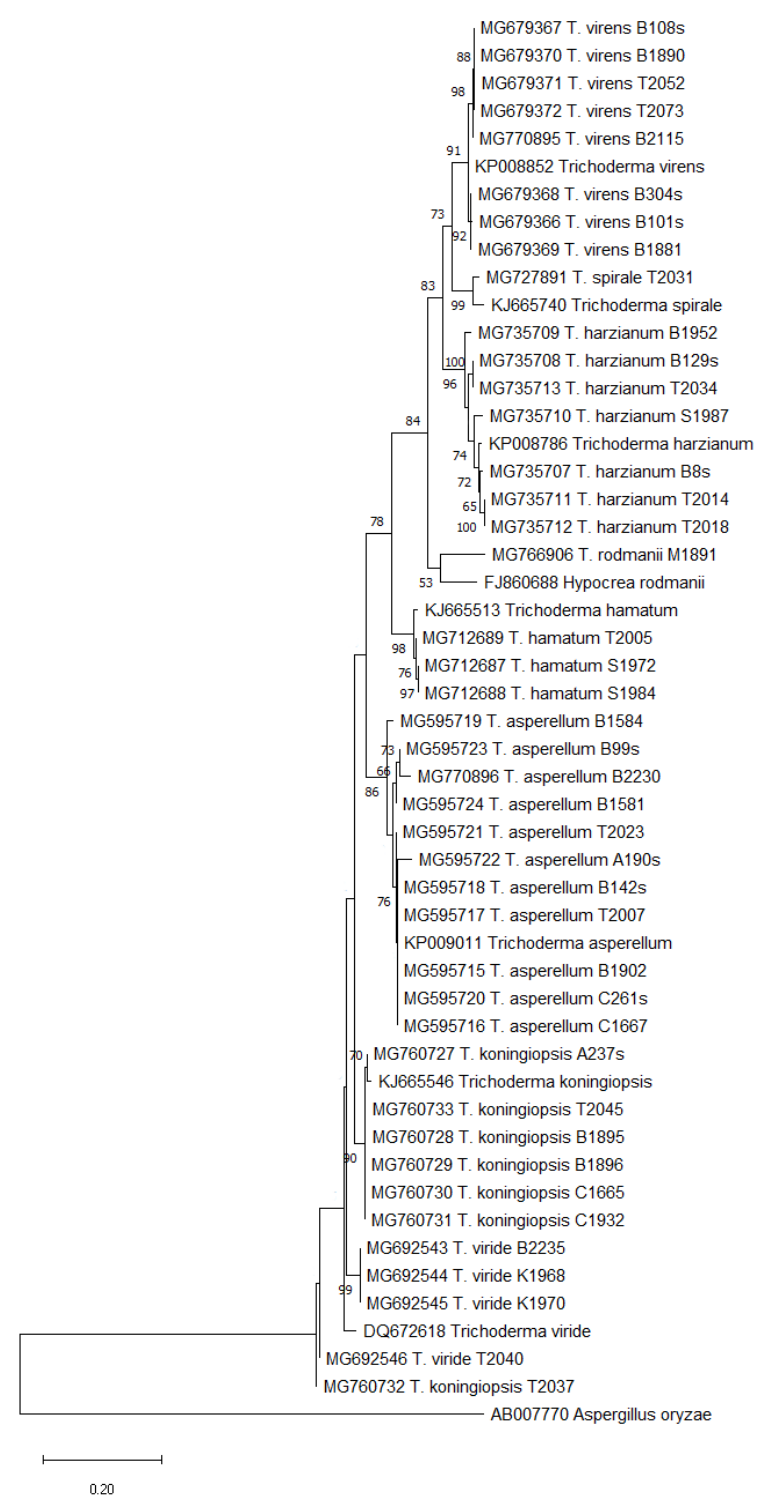

Figure 2: Phylogenetic tree generated from the Maximum Likelihood method based on the translation elongation factor 1-alpha sequences. The tree generated using Tamura-Nei model with bootstrap values of 1000 replications involved 42 sequences from Trichoderma isolates and an outgroup sequence of Aspergillus oryzae. All positions with less than $50 \%$ are not shown in the tree.

Macromorphology of $T$. hamatum in PDA plate is floccose sparse cottony from whitish at first then turned to yellowish-green in colour after more than 7 to 14 days (Figure 4A-B). The conidia production was denser in centre then towards the margins of PDA plate. $T$. hamatum growth rate on PDA ranged between 22.3-25.5 $\mathrm{mm} /$ day and cover the full plate within four days. The spores were produced gradually from yellowish to light green in colour at maturity. Conidiophores of $T$. hamatum were formed in long and thick with short and thick side branches (Figure 4C). The phialides were short swollen bottle-like pear-shaped (Figure 4D). The phialospores were ellipsoidal-shaped (Figure 4E). The conidia were oblong or ellipsoid, often with parallel sides, green, smooth shape. The chlamydospores present were at the terminal and intercalary in globose in shape with granulated (Figure 4F). For T. hamatum, in comparison with the research done by Jaklitsch and Voglmayr (2015), the characteristics of $T$. hamatum almost the same as the colony growth in yellow-brown or dull orange in colour on
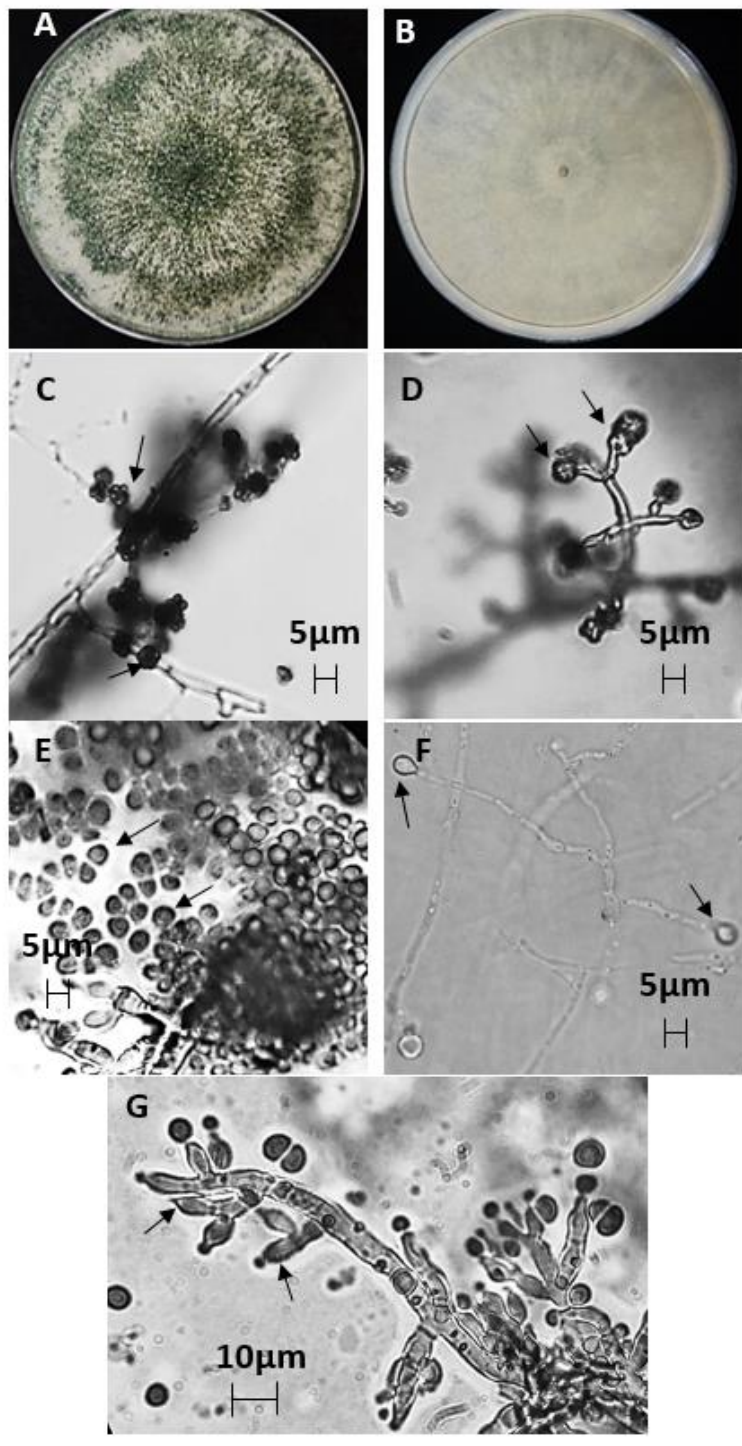

Figure 3: Morphological characteristics of $T$. asperellum. A-B: Colony features on PDA; C-D: Branches of conidiophores with spore masses; E: Phialospores (arrows); F: Chlamydospores (arrows); G: Phialides (arrow). 
Malays. J. Microbiol. Vol 17(1) 2021, pp. 80-89

DOI: http://dx.doi.org/10.21161/mjm.200893

Table 3: GenBank accession number of TEF 1-alpha Trichoderma isolates.

\begin{tabular}{|c|c|c|c|c|c|}
\hline No. & Isolates & Scientific name & Origin & Crop & GenBank accession no. \\
\hline 1 & A190s & T. asperellum & Bidor & oil palm & MG595722 \\
\hline 2 & A237s & T. koningiopsis & Segari & oil palm & MG760727 \\
\hline 3 & B8s & T. harzianum & Semenyih & oil palm & MG735707 \\
\hline 4 & B99s & T. asperellum & Banting & oil palm & MG595723 \\
\hline 5 & B101s & T. virens & Meru & rubber & MG679366 \\
\hline 6 & B108s & T. virens & Meru & rubber & MG679367 \\
\hline 7 & B129s & T. harzianum & Kajang & oil palm & MG735708 \\
\hline 8 & B142s & T. asperellum & Kajang & oil palm & MG595718 \\
\hline 9 & B304s & T. virens & Hulu Selangor & oil palm & MG679368 \\
\hline 10 & B1581 & T. asperellum & Tanjung Karang & paddy & MG595724 \\
\hline 11 & B1584 & T. asperellum & Tanjung Karang & paddy & MG595719 \\
\hline 12 & B1881 & T. virens & Dengkil & oil palm & MG679369 \\
\hline 13 & $\mathrm{~B} 1890$ & T. virens & Dengkil & oil palm & MG679370 \\
\hline 14 & B1895 & T. koningiopsis & Dengkil & banana & MG760728 \\
\hline 15 & B1896 & T. koningiopsis & Dengkil & banana & MG760729 \\
\hline 16 & B1902 & T. asperellum & Dengkil & banana & MG595715 \\
\hline 17 & B1952 & T. harzianum & Meru & banana & MG735709 \\
\hline 18 & $\mathrm{~B} 2115$ & T. virens & Dengkil & jackfruit & MG770895 \\
\hline 19 & B2230 & T. asperellum & Serdang & banana & MG770896 \\
\hline 20 & B2235 & T. viride & Serdang & banana & MG692543 \\
\hline 21 & C261s & T. asperellum & Cameron Highland & cabbage & MG595720 \\
\hline 22 & C1665 & T. koningiopsis & Maran & oil palm & MG760730 \\
\hline 23 & C1667 & T. asperellum & Maran & oil palm & MG595716 \\
\hline 24 & C1932 & T. koningiopsis & Maran & oil palm & MG760731 \\
\hline 25 & K1968 & T. viride & Langkawi & paddy & MG692544 \\
\hline 26 & K1970 & T. viride & Langkawi & paddy & MG692545 \\
\hline 27 & M1891 & T. rodmanii & Telok Mas & mango & MG766906 \\
\hline 28 & S1972 & T. hamatum & Kundasang & banana & MG712687 \\
\hline 29 & S1984 & T. hamatum & Kundasang & banana & MG712688 \\
\hline 30 & S1987 & T. harzianum & Kundasang & banana & MG735710 \\
\hline 31 & T2005 & T. hamatum & Bukit Besi & oil palm & MG712689 \\
\hline 32 & T2007 & T. asperellum & Bukit Besi & oil palm & MG595717 \\
\hline 33 & T2014 & T. harzianum & Bukit Besi & oil palm & MG735711 \\
\hline 34 & T2018 & T. harzianum & Bukit Besi & oil palm & MG735712 \\
\hline 35 & T2023 & T. asperellum & Bukit Besi & oil palm & MG595721 \\
\hline 36 & T2031 & T. spirale & Bukit Besi & oil palm & MG727891 \\
\hline 37 & T2034 & T. harzianum & Bukit Besi & oil palm & MG735713 \\
\hline 38 & T2037 & T. koningiopsis & Bukit Besi & oil palm & MG760732 \\
\hline 39 & T2040 & T. viride & Bukit Besi & oil palm & MG692546 \\
\hline 40 & T2045 & T. koningiopsis & Ketengah & oil palm & MG760733 \\
\hline 41 & T2052 & T. virens & Ketengah & oil palm & MG679371 \\
\hline 42 & T2073 & T. virens & Ketengah & oil palm & MG679372 \\
\hline
\end{tabular}

PDA. The microscopic observation of $T$. hamatum was typical for pachybasium-type conidiophores with ampulliform phialides.

Trichoderma harzianum on PDA plate rather lose or compact cottony tufts from whitish at first mycelia growth then to dull that dark green in color when increasing time. It formed 1-2 concentric rings with dark green conidial production (Figure 5A-B). The conidia production was denser in centre then towards the margins of PDA plate. Its produced no distinguishes odour however when being incubated in more than 14 days, some isolates will emit some pungent odour like 'coconut'. T. harzianum is rapid growth colonies on PDA that ranged between 21.0-25.0 $\mathrm{mm} /$ day and covers the full plate within four days.
Conidiophores of $T$. harzianum were formed in paired branches along the main mycelia axis (Figure 5C). The phialides naturally bend towards the apex and formed cylindrical shape which swollen-like at the middle (Figure 5D). The phialospores formed were abundant and accumulated at the tips of phialides and formed globose conidial head. The phialospores of $T$. harzianum were subglobose and short obovoid in shape (Figure 5E). The chlamydospores were at the terminal and intercalary in globose or oval (Figure 5F). For microscopic observation of $T$. harzianum, almost the same with Suhaida and Nur Ain Izzati (2013). Their mycelium, initially of a white color, acquired green, yellow shades, or remained white, due to 


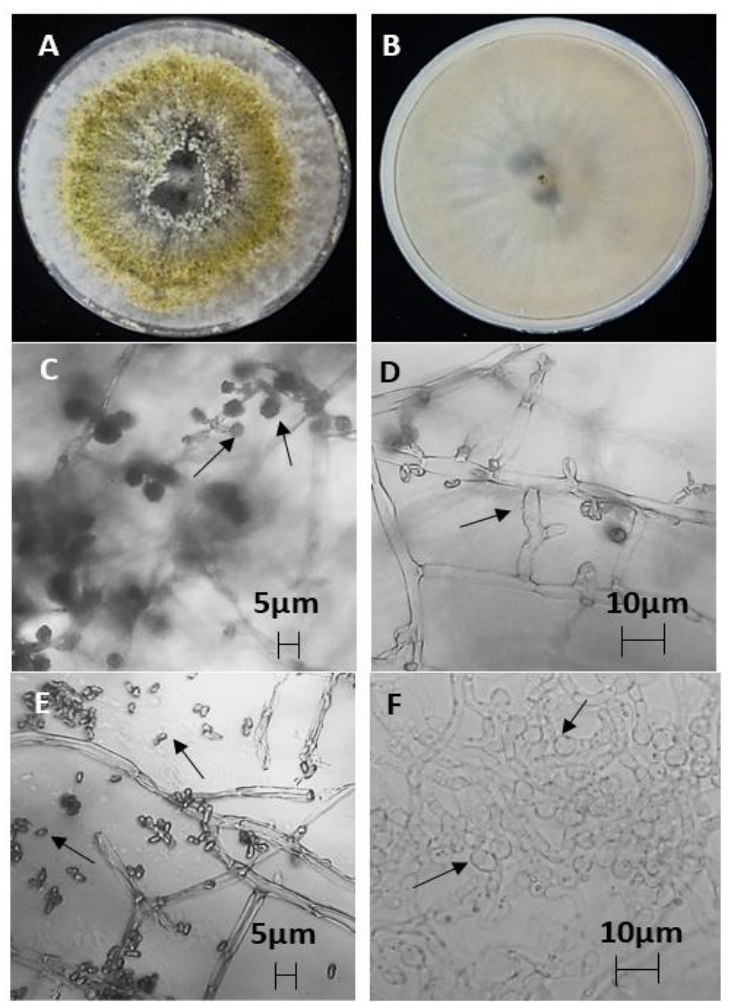

Figure 4: Morphological characteristics of T. hamatum. A$\mathrm{B}$ : Colony features on PDA; C: Branches of conidiophores with spore masses; D: Phialide (arrow); E: Phialospores (arrows); F: Chlamydospores (arrows).

the abundant production of conidia, which presents subglobous to ellipsoid conidia, ampuliform phialides.

Macromorphology of $T$. koningiopsis in PDA plate is cottony tufted whitish in colour (Figure 6A-B); sometimes when incubated more than 14 days if formed slightly green in colour indicates green conidia. T. koningiopsis colonies growth on PDA was ranged between 20.5-24.7 $\mathrm{mm} /$ day and covers the full plate within four days. Conidiophores of $T$. koningiopsis were formed in long branches (Figure 6C). The phialides were long than $T$. harzianum and $T$. asperellum (Figure 6D). The phialospores were ellipsoidal with smooth-walled (Figure $6 \mathrm{E})$. The chlamydospores present were at the terminal and intercalary in globose in shape with granulated (Figure 6F). Based on Qian et al. (2013), T. koningiopsis (strain F13V-2) was firstly reported as pathogen of leaf blight disease of Curcuma wenyujin in China, the growth of $T$. koningiopsis on the PDA were the same, which is white mycelium. However, the colonies grew up to about $54 \mathrm{~mm}$ in diameter within 33 hours and turned light green after being incubated for 72 hours different with obtained $T$. koningiopsis which can only turned to green after incubation more than 14 days. Conidia were green, smooth, ellipsoid, 3-4 × 2-3 $\mu \mathrm{m}$ in size (Qian et al., 2013).

In PDA plate, T. rodmanii culture is floccose tufted from whitish to slight dark green in colour, sometimes when incubate more than 14 days if formed powdery green conidia. The conidia production was denser outside then toward the margins of PDA plate (Figure 7A-B). $T$. rodmanii colonies growth on PDA was ranged between 21.5-25.5 mm/day and covers the full plate within four days. Conidiophores of $T$. rodmanii were in paired branches on the tips (Figure 7C). The phialides were longer than T. harzianum and T. asperellum (Figure 7D). The phialospores were elliptical-subcylindrical (Figure $7 \mathrm{E})$. The chlamydospores present were at the terminal and intercalary in globose and oval with granulated (Figure 7F). In comparison with previous study done by Degenkolb et al. (2008), T. rodmanii has slower rate of growth, but the strains obtained having smaller globose conidia and phialides and partially sterile conidiophores to distinguish this species.

Trichoderma spirale shown macromorphology in PDA plate is cottony floccose tufted from whitish to slight dull green in colour at the centre, when incubated more than 14 days the dull green was expand from the centre to the margins. It formed 1-2 concentric rings with green conidial production at the centre (Figure $8 \mathrm{~A}-\mathrm{B}$ ). $T$. spirale colonies growth on PDA was ranged between 21.5-25.5 mm/day and covers the full plate within four days. Conidiophores of $T$. spirale were formed in long and
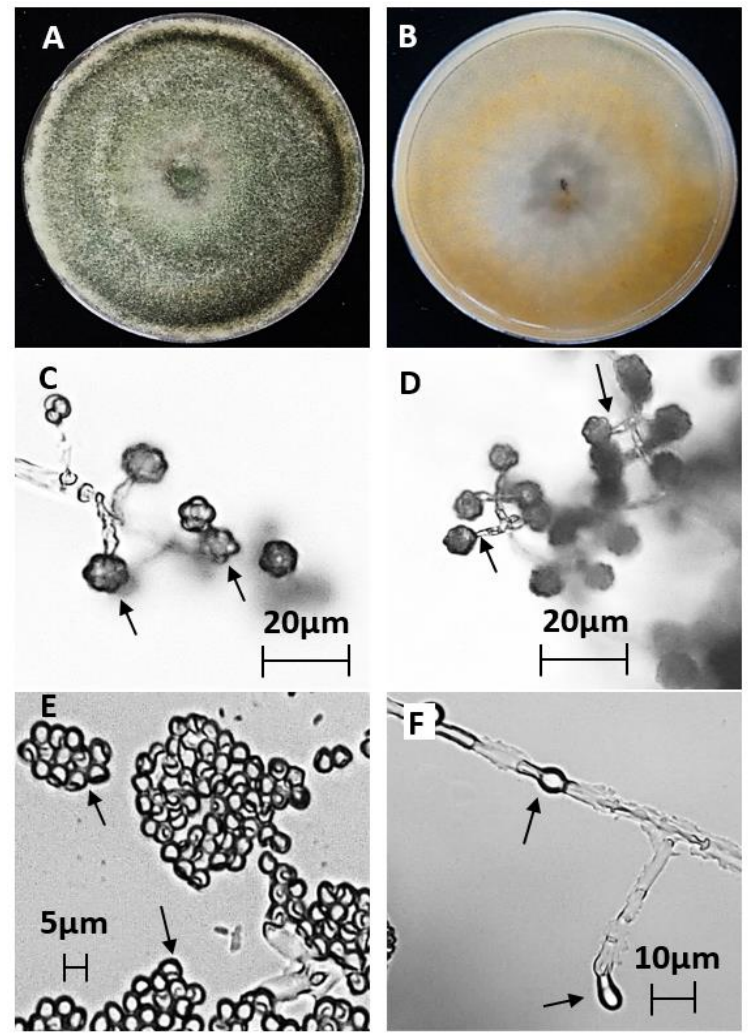

Figure 5: Morphological characteristics of $T$. harzianum. A-B: Colony features on PDA; C: Branches of conidiophores with spore masses; D: Phialides (arrows); E: Phialospores (arrows); F: Chlamydospores (arrows). 
Malays. J. Microbiol. Vol 17(1) 2021, pp. 80-89 DOI: http://dx.doi.org/10.21161/mjm.200893

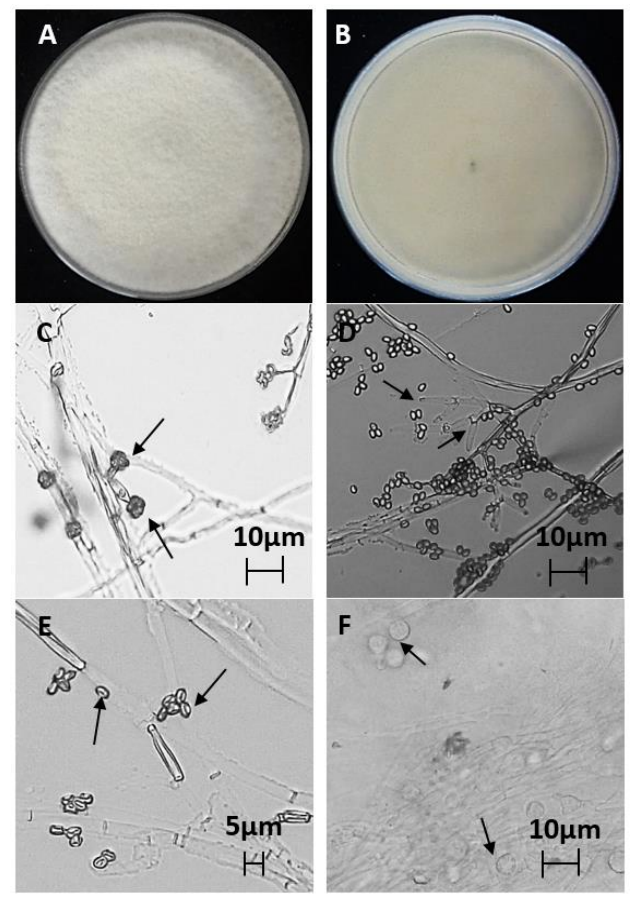

Figure 6: Morphological characteristics of T. koningiopsis. A-B: Colony features on PDA; C: Branches of conidiophores with spore masses; D: Phialides (arrows); E: Phialospores (arrows); F: Chlamydospores (arrows).

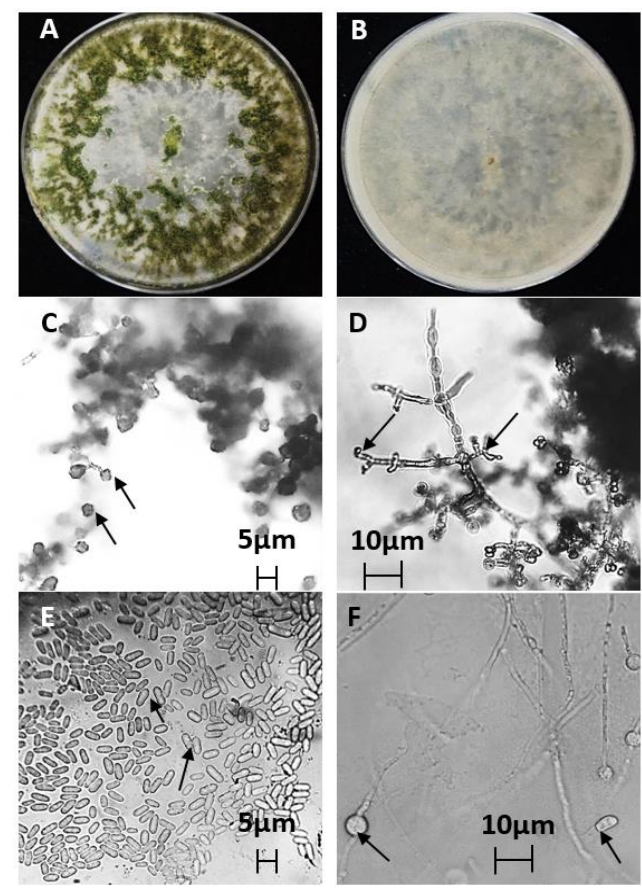

Figure 7: Morphological characteristics of $T$. rodmanii. AB: Colony features on PDA; C: Branches of conidiophores with spore masses; D: Phialides (arrows); E: Phialospores (arrows); F: Chlamydospores (arrows).
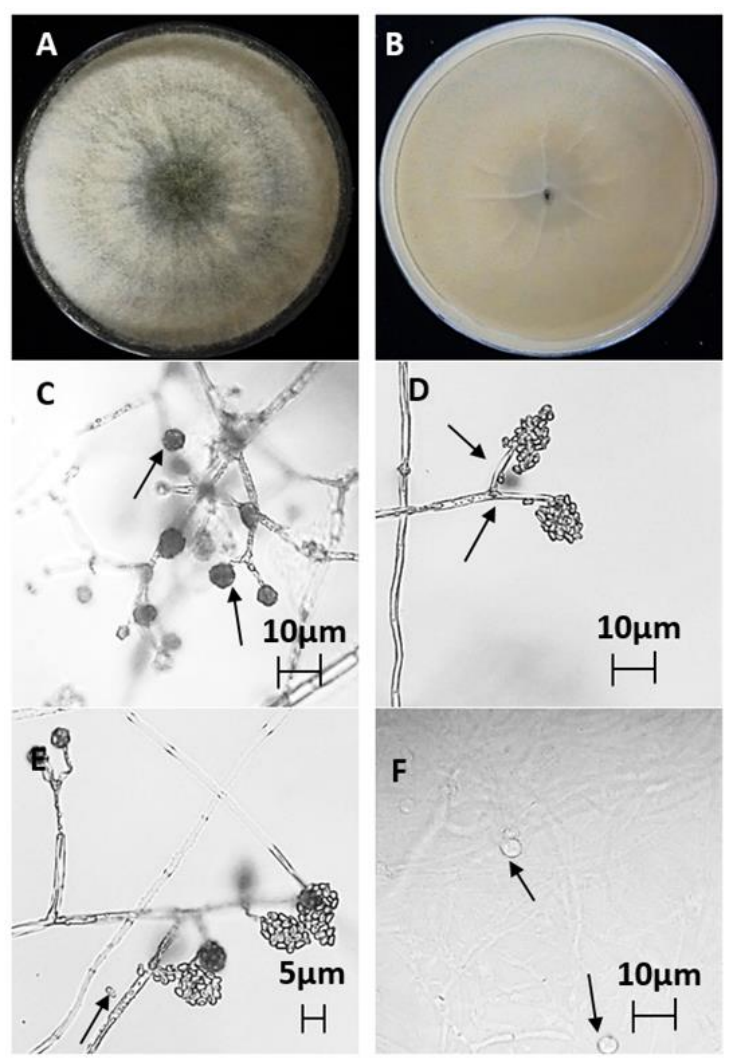

Figure 8: Morphological characteristics of T. spirale. A-B: Colony features on PDA; C: Branches of conidiophores with spore masses; D: Phialides (arrows); E: Phialospores (arrow); F: Chlamydospores (arrows).

repeatedly paired branches along the main axis (Figure $8 \mathrm{C})$. The phialides were similar structured as $T$. koningiopsis, which are long and paired in the tip of branches (Figure 8D). The phialospores were ellipsoidal (Figure 8E). The chlamydospores present were at the terminal and intercalary in globose in shape with granulated (Figure 8F). Jang et al. (2017) reported $T$. spirale strains obtained from the studied showed greyish green to dark greyish green and some strains with olive yellow pigment and abundant of aerial mycelium on PDA. The conidial production forming in broad concentric rings. The conidia are smooth, oblong to ellipsoidal in size of 4.1-5.1 $\times$ 2.5-2.8 $\mu \mathrm{m}$. The chlamydospores were not observed. The conidiophores are broad fertile branches arising from the base. The phialides arising in dense clusters, nearly doliiform, short and wide at the base.

Macromorphology of $T$. virens in PDA plate is fluffy cottony tufted from whitish to dull green in colour. It also formed 1-2 concentric ring(s) with dull green conidial production. The conidia production was denser at the concentric ring at the centre and towards the margins of PDA plate (Figure 9A-B). Trichoderma virens is rapid growth colonies on PDA that ranged between 20.5-24.5 $\mathrm{mm} /$ day and covers the full plate within four days. 


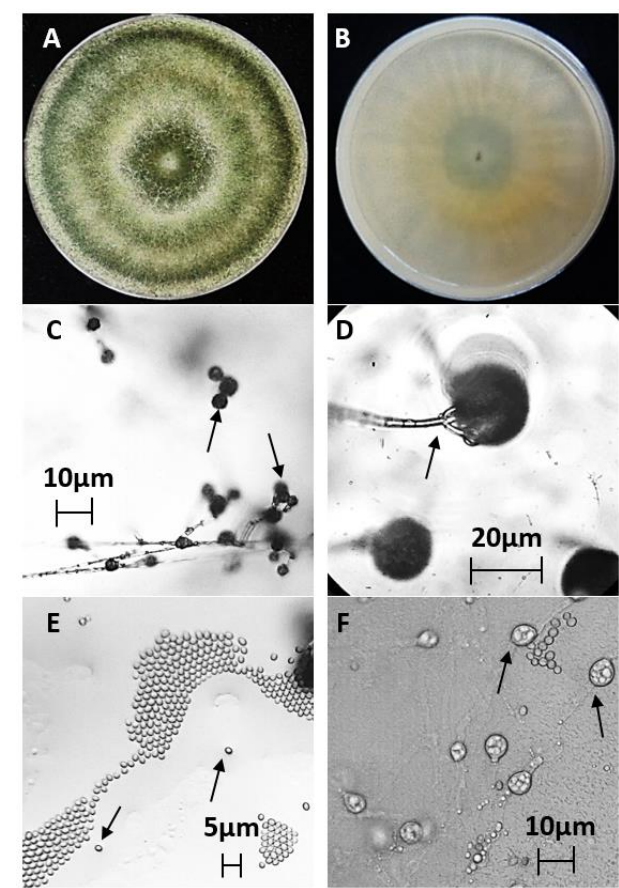

Figure 9: Morphological characteristics of T. virens. A-B: Colony features on PDA; C: Branches of conidiophores with spore masses; D: Phialide (arrow); E: Phialospores (arrows); F: Chlamydospores (arrows).

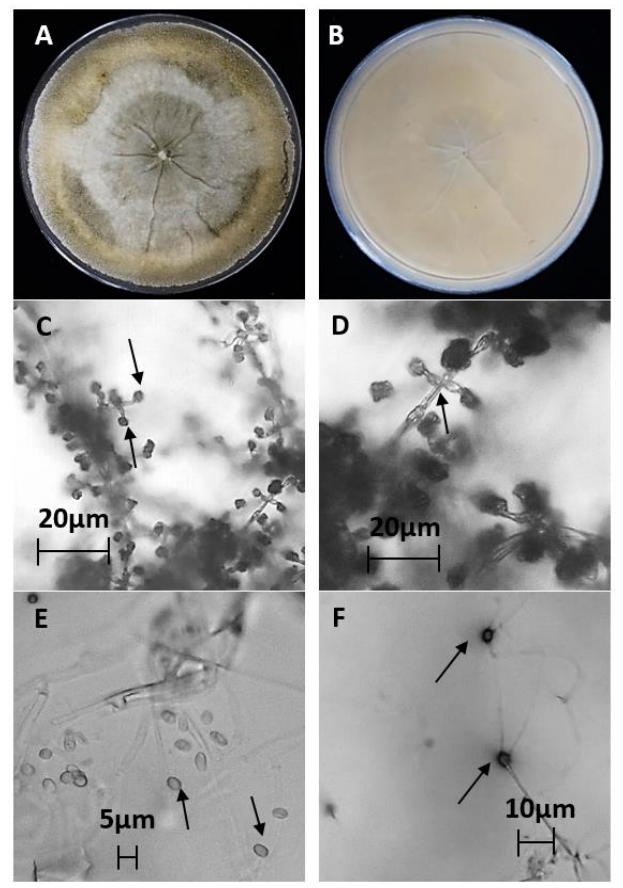

Figure 10: Morphological characteristics of T. viride. A-B: Colony features on PDA; C: Branches of conidiophores with spore masses; D: Phialide (arrow); E: Phialospores (arrows); F: Chlamydospores (arrows).
Conidiophores of $T$. virens were formed uneven paired branched of phialides (Figure 9C). The phialides were cylindrical shaped with enlarged at the branched body (Figure 9D). The phialospores were cluster accumulated at the tips of phialides in globose (Figure 9E). The chlamydospores presented were at the terminal and intercalary in globose and oval with granulated (Figure 9F). In comparison with Odeniyi et al. (2012), the conidia of $T$. virens appear dry but in some strains, they may be held in drops of clear green or yellow liquid. Typically, conidia of most strains were globose and smooth.

Trichoderma viride macromorphology in PDA plate is loose floccose cottony tufted from whitish to green-yellow in colour. It formed 1-3 concentric rings with green conidial production (Figure 10A-B). The conidia production was denser at the concentric ring whether at the centre and at the margins of PDA plate. T. viride growth colonies on PDA ranged between 21.0-25.0 $\mathrm{mm} /$ day and cover the full plate within four days. Conidiophores of $T$. viride were formed in uneven paired phialides like whorled shaped (Figure 10C). The phialides were cylindrical swollen near the tips it almost exactly like $T$. koningii but some of the T. viride phialides were bend at the tips (Figure 10D). The phialospores of the T. viride were subglobose or obovoid (Figure 10E). The chlamydospores were at the terminal and intercalary in globose or oval (Figure 10F). Based on research done by Shah et al. (2012), in comparison, T. viride appeared a bit granular with green conidia distributed, an irregular yellow zone without conidia was present and white pustules were found on the green conidia. For microscopic characterization, the conidia of $T$. viride were globose with size of $3.0 \times 2.8 \mu \mathrm{m}$.

\section{CONCLUSION}

According to the results obtained in this work, Trichoderma isolates in the agricultural soil in Malaysian ecosystems are diverse. The studies of those Trichoderma isolates on their potential antagonistic interaction can be explored in the future for improving environmental health.

\section{ACKNOWLEDGEMENTS}

The authors gratefully acknowledge Mycology lab assistant, Mrs. Nor Hidayah Husain for technical assistance and appreciate those who provided valuable and constructive suggestions during the planning and development of this research work. This research was supported by grants by the Malaysia Ministry of Higher Education (MOHE) for Fundamental Research Grant Scheme (FRGS/1/2018/STG03/UPM/02/12/5540129).

\section{REFERENCES}

Ahmad, F., Husain, F. M. and Ahmad, I. (2011). Rhizosphere and root colonization by bacterial inoculants and their monitoring methods: A critical area in PGPR research. In: Microbes and Microbial 
Technology: Agricultural and Environmental Applications. Ahmad, I. (ed.). Springer, Berlin, Germany. pp. 363-391.

Bissett, J., Gams, W., Jaklitsch, W. and Samuels, G. J. (2015). Accepted Trichoderma names in the year 2015. International Mycological Association Fungus 6(2), 263-295.

Contreras-Cornejo, H. A., Macias-Rodriguez, L., Cortes-Penagos, C. and Lopez-Bucio, J. (2009). Trichoderma virens, a plant beneficial fungus, enhances biomass production and promotes lateral root growth through an auxin-dependent mechanism in Arabidopsis. Plant Physiology 149, 1579-1592.

Degenkolb, T., Dieckmann, R., Nielsen, K. F., Gräfenhan, T., Theis, C., Zafari, D., Chaverri, P., Ismaiel, A., Brückner, H., Döhren, H. V., Thrane, U., Petrini, O. and Samuels, G. J. (2008). The Trichoderma brevicompactum clade: A separate lineage with new species, new peptaibiotics and mycotoxins. Mycological Progress 7(3), 177-219.

Easa Hasan, Z. A., Mohd Zainudin, N. A. I., Aris, A., Ibrahim, M. H. and Yusof, M. T. (2020). Biocontrol efficacy of Trichoderma asperellum - enriched coconut fiber against Fusarium wilts of cherry tomato. Journal of Applied Microbiology 129(4), 991-1003.

Elamawi, R. M., Al-Harbi, R. E. and Hendi, A. A. (2018). Biosynthesis and characterization of silver nanoparticles using Trichoderma longibrachiatum and their effect on phytopathogenic fungi. Egypt Journal of Biological Pest Control 28(1), 28.

Garbeva, P., van Veen, J. D. and van Elsas, J. D. (2004). Microbial diversity in soil: Selection of microbial populations by plant and soil type and implications for disease suppressiveness. Annual Review Phytopathology 42, 243-270.

Guilger, M., Pasquoto-Stigliani, T., Bilesky-Jose, N., Grillo, R., Abhilash, P. C., Fraceto, L. F. and de Lima, R. (2017). Biogenic silver nanoparticles based on Trichoderma harzianum: synthesis, characterization, toxicity evaluation and biological activity. Scientific Reports 7, $\mathbf{4 4 4 2 1 .}$

Harman, G. E. (2000). Myths and dogmas of biocontrol: Changes interceptions derived from research on Trichoderma harzianum (T22). Plant Disease 84(4), 377-393.

Howell, C. R. (2003). Mechanisms employed by Trichoderma species in the biological control of plant disease: The history and evolution of current concepts. Plant Disease 87(1), 4-10.

Huang, W. Y., Cai, Y. Z., Surveswaran, S., Hyde, K. D., Corke, H. and Sun, M. (2009). Molecular phylogenetic identification of endophytic fungi isolated from three Artemisia species. Fungal Diversity 36, 6988.

Jaklitsch, W. M. and Voglmayr, H. (2015). Biodiversity of Trichoderma (Hypocreaceae) in Southern Europe and Macaronesia. Studies in Mycology 80, 1-87.

Jang, S., Jang, Y., Kim, C-W., Lee, H., Hong, J-H., Heo, Y. M., Lee, Y. M., Lee, D. W., Lee, H. B. and Kim, J. J. (2017). Five new records of soil-derived
Trichoderma in Korea: $T$. albolutescens, $T$. asperelloides, $T$. orientale, $T$. spirale and $T$. tomentosum. Mycobiology 45(1), 1-8.

Kumar, S., Stecher, G., Li, M., Knyaz, C. and Tamura, K. (2018). MEGA X: Molecular Evolutionary Genetics Analysis across computing platforms. Molecular Biology and Evolution 35(6), 1547-1549.

Lorito, M., Woo, S. L., Harman, G. E. and Monte, E. (2010). Translational research on Trichoderma: From 'Omics to the field. Annual Review of Phytopathology 48, 395-417.

Odeniyi, O. A., Onilude, A. A. and Ayodele, M. A. (2012). Characteristics of a $\beta-1,4-D$ endoglucanase from Trichoderma virens wholly applied in palm - fruit husk-based diet for poultry layers. Brazilian Journal of Microbiology 43(4), 1467-1475.

Qian, Y. S., Cai, S., Huo, Y. N., Mao, P. P., Wang, H. Z. and $\mathrm{Wu}$, J. B. (2013). First report of leaf blight disease of Curcuma wenyujin caused by Trichoderma koningiopsis in China. Journal of Plant Pathology 95( S4), 69-77.

Samuels, G. J. (2006). Trichoderma: Systematics, the sexual state, and ecology. Phytopathology 96(2), 195206.

Samuels, G. J., Chaverri, P., Farr, D. F. and McCray, E. B. (2012). Trichoderma online, systematic mycology and microbiology laboratory. Agricultural Research Service (ARS), United States Department of Agriculture https://nt.ars-grin.gov/fungaldatabases/ [Retrieved on 16 November 2014].

Shah, S., Nasreen, S. and Sheikh, P. A. (2012). Cultural and morphological characterization of Trichoderma spp. associated with Green mold disease of Pleurotus spp. in Kashmir. Research Journal of Microbiology 7(2), 139-144.

Suhaida, S. and Nur Ain Izzati, M. Z. (2013). The efficacy of Trichoderma harzianum T73s as a biocontrol agent of fusarium ear rot disease of maize. International Journal of Agriculture and Biology 15(6), 1175-1180.

Vinale, F., Sivasithamparam, K., Ghisalberti, E. L., Marra, R., Woo, S. L. and Lorito, M. (2008). Trichoderma-plant-pathogen interactions. Soil Biology and Biochemistry 40(1), 1-10.

Wijesinghe, C. J., Wijeratnam, S. W., Samarasekara, J. K. R. R. and Wijesundera, R. L. C. (2010). Identification of Trichoderma asperellum from selected fruit plantations of Sri Lanka. Journal of the National Science Foundation of Sri Lanka 38(2), 125-129. 